\title{
The CIF Scene
}

\section{Across the Manager's Desk}

\section{NEW MEMBERS}

\section{Active}

Edward Blackmore

17 Peterson Dr.

Gander, Nfld.

N.G. Brocard

Simpson Timber Co.

Box 1079

Whitecourt, Alta.

TOE 2LO

George Brown

716 - 6th St. S.

Kenora, Ont.

P9N 1 N8

F.W. Daniels

Box 128

Whitecourt, Alta.

TOE 2LO

W.R. Dempster

Simpson Timber Co.

Box 1079

Whitecourt, Alta.

TOE 2LO

W.H. Dryer

c/o Evans Products Ltd.

Box 170

Golden, B.C.

Madan M. Pandila

Box 473

Hudson Bay, Sask.

SOE OYO

\section{G.D. Smith}

Simpson Timber Co.

Box 1079

Whitecourt, Alta

TOE 2LO
It is not always true that "bigger" is "better" but it is generally accepted that any organization representing a group of people is strengthened as its numbers increase. At the recent Annual Meeting there was much discussion on ways and means of increasing the membership of the Institute. Throughout the meetings of the Executive Committee, the Board of Directors and the General Members, the need to increase membership was continually expressed. Whether the discussions were of finances, the effectiveness of Working Groups, the improvement of forestry practice or the general strength of the Institute, the importance of increased membership was apparent.

It was agreed by the members of the Board of Directors that a full scale membership campaign be mounted and that the Executive Committee, Board of Directors, Sections and individuals concentrate in the coming year on this effort.

As a starting point, Sections are requested to appoint a strong Membership Committee with an enthusiastic Chairman and energetic members. It would be the task of these committees to locate, list, approach and invite potential members to join. Many Sections already have Membership Committees. Sections without such committees are urged to form them immediately in order to forward the campaign as soon as possible.

\section{Potential Members}

Potential members include all people working in forestry. Graduate foresters can become members immediately and graduates of related disciplines, either working in forestry or who have "indicated interest in forestry and who are considered to be in a position to contribute to the advancement of forestry principles" may join.

By-laws introduced this year also make forestry technician students eligible for student membership and they may become affiliate members immediately on graduation.

Affiliate members may become Active members as soon as they hold "responsible forestry positions" or if they have "special qualifications and long and valuable experience".

\section{Competition}

In order to encourage Sections and verify their intent, the Executive Committee has decided to offer awards to the two Sections who enlist the most new members. A box score will be published in The Forestry Chronicle and the competition will run from October 15, 1975 to August 15, 1976.

Sections are reminded that the greatest immediate attraction for new members is regular and interesting meetings. The opportunity provided at meetings to rub shoulders with and exchange ideas with others of like interests is a valuable professional experience. There are many advantages to becoming a member of the Institute such as The Forestry Chronicle, the Group Insurance and Pension Plans and the opportunity to join the Working Groups. But the Section meeting has the greatest potential for the realization of the Institute's objectives.

All Institute members are asked to give their full support to this campaign. Your membership committee will be counting on you to help, please assist them in any way you can.

A. G. Racey 
D. L. Wotton

School of Forestry

Lakehead University

Thunder Bay "P", Ont.

\section{Affiliate}

M.A. Penn

Evans Products Ltd.

Box 170

Golden, B.C.

Roy Ross

Box 1765

Whitecourt, Alta.

TOE 2LO

\section{Student}

J.K. Antoniak

140 Robinson Dr.

Thunder Bay, Ont.

R.J. Berezowsky

8615 - 77th St.

Edmonton, Alta.

Patti Brown

\#719 Mackenzie Hall

116 St. \& 87th Ave.

Edmonton, Alta.

T6G $2 \mathrm{H} 6$

D.J. Buchan

\#904 - 9618-112 St.

Edmonton, Alta.

Timothy C. Burns

11724 - 48 Ave.

Edmonton, Alta.

\section{J. Burrows}

11054 - 89th Ave

Edmonton, Alta.

Wm. O. Campsall

414 Dufferin

Thunder Bay, Ont.

P7B 1N6

Wm. Cheliak

206 Banning St.

Thunder Bay "P", Ont.

David Crevier

17056 Valley

Pierrefonds, P.Q.

H9J 1 G5

\section{J.E. Fauville}

9924 - 87th Ave.

Edmonton, Alta.

John F. Foster

36 Front St.

Thunder Bay, Ont.

P7A 4K2

D.A. Graham

8819 - 98th St.

Grande Prairie, Alta.

Wendy Ann Grant

Lakehead University Res.

Thunder Bay, Ont.

P7B 5E1

\section{Pierre Gravel}

Corona Hotel

106 Jasper Ave.

Edmonton, Alta.
A. Groot

Box 107 - 21 Classic Ave.

Toronto, Ont.

M5S $1 \mathrm{~A} 1$

Catherine Harper

Apt. 312 - 745 Graham

Fredericton, N.B.

Richard G. B. Hilton

148 S. Rockwood Ave.

Thunder Bay, Ont.

R.L. Ireland

197 Southridge

45 Ave \& 106 St.

Edmonton, Alta.

Tan A. Ishak

\#2A, 9012 - 112 St.

Edmonton, Alta.

T6G 2C5

Norman Krannitz

R.R.\#1

Terra Cotta, Ont.

LOP 7NO

John Lai

Box 7713 - Stn. A.

Edmonton, Alta.

Douglas Lantagen

c/o Newman Centre

Burlington, Vermont 05855

J.S. MacPhail

370 Woodbine Ave.

Peterborough, Ont.

$\mathrm{K} 9 \mathrm{H} 1 \mathrm{P} 3$

Anita L. Maloney

11201 - 102 St.

Edmonton, Alta.

N.R. Miller

378 - 2nd St. N.W.

Medicine Hat, Alta.

John Monczka

7 Kimberdale Cres.

Agincourt, Ont.

W. N. Moryto

360 Sunnyside Ave.

Toronto, Ontario

M6R 2R8

B.J. Muhly

1B-8904 - 112 St.

Edmonton, Alta.

Marty O'Bryne

$\# 3-4903$ Varsity N.W

Calgary, Alta.

Ross W. Parker

9814 - 84th Ave.

Edmonton, Alta.

M.K. Pelchat

7902 - 92nd Ave

Edmonton, Alta.

R. Pulkki

249 Munro St.

Thunder Bay "N", Ont.

P7A 2 N1.
S.P. Rose

769 Regent St.

Fredericton, N.B.

Claudia Schaerer

Lakehead University Res.

Thunder Bay, Ont.

Janet Schilf

10512 - 70 Ave.

Edmonton, Alta.

Wayne A. Smith

2620 Chestnut St.

Thunder Bay "F", Ont.

E.I. Stjernberg

216 - 325 Bogert Ave.

Willowdale, Ont.

D.G. Tamminen

R.R.\#12

Thunder Bay, Ont.

Julius T. Tarjan

496 Westmorland

Fredericton, N.B.

Hedy A. Wiecek

219 Willowridge Rd.

Weston, Ont.

D.M. Wishart

3 Cypress Ave.

Sherwood Park, Alta.
Boundary lines that last so long they may have to be painted over to get rid of, but hardly ever to keep. That's the kind of durability you can expect from Nelson Boundary Paint!

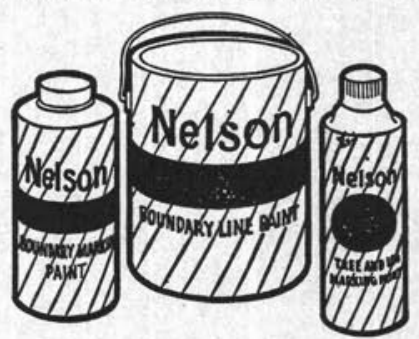

NELSON BOUNDARY LINE PAINT is a heavy-bodied paint made from specially formulated high solids material. It brushes easily, produces bright-colored line free from sags and runs, remains stabilized in the can and almost never needs repainting.

Available in round gallons and quarts for brush; square gallons and quarts for Nel-Spot guns; 16 oz. aerosol cans; six colors.

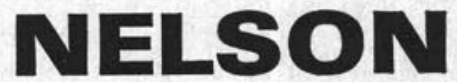

Canadian Distributors:

CANADIAN WARREN PINK LTD.

. Catharines, Ont. - Vancouver, B.C. GEORGE H. HEWITT CO. LTD.

Vancouver, B.C. 


\section{Section News}

\section{Algonquin}

The Algonquin Park controversy rages on. On behalf of the Algonquin Section, J. O. Smith presented a brief to the Provincial Parks Council of Ontario at a meeting held in Bancroft on September 26. The brief indicated the Section's support of the multiple or integrated land use concept and the view that there is adequate area to meet everyone's needs. It recognized that the objectives of the Master Plan can only be met with a spirit of cooperation. Compromises will be necessary, which must not be made for the sake of political expediency, but rather must be based on sound ecological principles administered by knowledgeable forest managers backed by sound basic research. The brief stated that we must not be afraid to demonstrate to the public how to cut trees and regenerate the forest by compatible means. In short, if we are to succeed in the stated objectives of the Master Plan, good silviculture as well as good overall management is necessary.

Although the meeting was well attended, the C.I.F. brief and one comment from the floor were the only reference to Forestry. Three points reoccurred repeatedly from the Fish and Game Clubs and local people:

1. They want small outboard motors retained.

2. They want wheels retained to assist portaging.

3. They were critical of the Plan's effective elimination of older and infirm people from the centre of the Park.

J. O. notes that this strong reaction from the ordinary recreationists was predicted by the logging interests during the early Algonquin Park controversy.

A few days after J. O. Smith so ably represented the Section at the Provincial Parks Council meeting, five other members were in attendance at the C.I.F. Annual Meeting in Montreal; M. I. Moore, C. E. Van Wagner, A. E. Vietinghoff, B.S.P. Wang, and C. W. Yeatman.

The first meeting of the '75-'76 season was held in Mattawa on October 24 with a trip to Olrig Township to inspect "strip clear-cutting" in tolerant hardwoods on the Sklar Furniture Ltd. Timber Licence and a tour of that company's sawmill and dimension plant. The business meeting was followed by a panel discussion on the management system seen earlier in the day. The panel, chaired by Bill Fullerton, consisted of a provincial biologist, Roger Wolfe; Sklar Woods Manager, Paul Swindle, and a provincial silviculturist, Jukka Heikurinen. Considerable discussion was gener- ated, both on the site and during the meeting. The general consensus seems to have been that although not every-one was convinced that this was the ideal treatment for the area, the various parties involved, Fish and Wildlife, Timber, and Industry, were to be commended for their cooperative effort towards positive action.

The primary management objective was the production of industrial hardwood, with the maintenance of a viable deer herd as a secondary objective. The treatment involves a three-strip system, each strip being three chains wide. The strips are to be cut at about five year intervals, with the first strips being cut in the winter of ' $74-' 75$. Some form of scarification is planned. A similar system of strip cutting was initiated in 1956 in Mulock Township, northeast of North Bay, with reasonable success. The system does present some problems, especially to the cutter, due to the current poor market for roundwood pulp and the fact that the system restricts his ability to select areas for summer or winter cutting.

\section{B. D. Haddon}

\section{Cariboo}

The first meeting of the $1975 / 76$ session was held on October 23. General business, including the possibility of establishing a demonstration forest was discussed. Doug Wilson, our past chairman, was our guest speaker and he described the activities at the annual meeting in Montreal.

The Pearse Royal Commission on Forest Resources continues to be a hot item on the B.C. forestry scene. The Cariboo Section presented a brief to the Commission in Prince Rupert on September 11, 1975. Our submission was based on the 1975 C.I.F. Forest Land Policy Statement. The brief was presented by Frank Renshaw and Bob Baker and among other things called for:

1. Re-evaluation of cut allocations.

2. Further flexibility in cut control administration.

3. Establishment of a "Silviculture and Reforestation Fund".

4. Careful planning of major extraction routes.

5. Increased education regarding natural resources at all levels of public education.

The Cariboo Section Third Annual Tree Planting Picnic went off without a hitch on September 20 , with about 90 adults, kids and dogs attending. 
Thanks go to Laverne Merkel, who was the major behind-the-scenes-force, and the B.C. Forest Service for supplying seedlings, Speedy Printers for supplying achievement certificates, Netherlands Overseas Mills Ltd. for a cash donation and the College of New Caledonia for supplying a bus and driver.

\section{F. Lowenberger}

\section{Vancouver Island}

\section{Sponsors Forestry Tour of Eastern Europe}

The Vancouver Island Section is sponsoring a forest study tour to eastern Europe, May 12 to June 11, 1976.

The tour will begin and end in Vienna although air transport from Vancouver to Vienna via London, and return, will be included in the package.
The tour, under the direction of Vancouver Island Section member Dr. O. Sziklai, R.P.F., will leave Vienna May 16 by motor coach and will cover Czechoslovakia, Hungary and Yugoslavia, returning to Vienna on June 10.

Wives may wish to accompany members and so arrangements will be made for concurrent sightseeing trips together with opportunities for sampling local colour and atmosphere.

Those who wish to participate in this tour should advise the Vancouver Island Section as soon as possible.

An itinerary, cost figure, and other details will then be provided before a firm decision must be made.

Reply to K. P. Campbell, Secretary, Vancouver Island Section, 675 Burley Drive, West Vancouver, B.C.

\section{\# 50 \& 25 Years}

\section{TWENTY-FIVE YEARS}

What problems in silviculture are amenable to research? First, I would put the determination of the silvical characteristics of species. These are as important to the forester as the properties of the elements are to the chemist. They include such features as seeding habits, seed bed requirements, response to the various site factors, and other characters as yet unknown. In order for the forester to produce the maximum quantity and quality of wood, in order to practise good silviculture, he must know the behaviour of each species under all existing conditions.

Of equal importance is the recognition of the various kinds of sites or habitats on which trees grow. The main features controlling the kind of site are soil and climate, so research in this field will require the help of soils scientists and climatologists. Not only must we be able to recognize the various kinds of sites, we must also learn their properties with regard to light, heat, nutrients, etc., so we can better understand their effect on trees. Until we learn to recognize sites, we cannot select suitable areas for research and we cannot apply the results of research. We all know the importance of site in connection with yield. I am convinced that site will be even more important in connection with the silvicultural treatment of stands. A treatment that will work on one site may be a failure on another.

Tree breeding is another field where research can make a contribution to forestry. The possibilities here are enormous. The increased yields that can be obtained by good silviculture are probably small compared with the increased yields that will result from the planting of superior trees. Forest genetics is a new field but I think we can expect great things here in the future.

J. L. Farrar.

\section{FIFTY YEARS}

Canadian foresters mourn the loss of Filibert Roth, the only member of the profession who had been elected an honourary member of our Society. His death removes from the family of foresters one of its pioneers who broke the trail and blazed the way for succeeding generations.

He knew the woods from long and close contact with them from his youth; and later, when he became a teacher of and a leader in forestry, this early experience gave a realism and deep conviction that could only have come from an intimate, personal knowledge of the forest. He was a born teacher possessed of a wonderful imagination, unexcelled ability for conveying ideas by word pictures, and a sympathetic understanding of the men who lived and worked in the woods. He swayed and influenced his students as no other teacher has yet done. His love for them deservedly earned for him the name of "Daddy Roth". His idealism, his unfailing faith in the future of forestry, even in the dark hours, will live in the hearts of his students throughout their lives, and will serve as a constant source of inspiration and courage.

Only what was mortal of Filibert Roth dies; his spirit will live forever and be a beacon of hope, courage and faith to foresters.

Resolution passed by the Society of American Foresters at their Annual Meeting in December, 1925. 